\title{
“O FILHO ETERNO”: A BIOPOLÍTICA E A IMAGEM DO ANORMAL
}

\section{“O FILHO ETERNO": THE BIOPOLITICS AND THE IMAGE OF THE ABNORMAL}

\section{Daniel de Oliveira Gomes*}

Resumo: O presente artigo estuda vários aspectos teóricos do romance de Cristóvão Tezza, "O filho eterno", considerando, sobretudo, a teoria de Michel Foucault sobre os anormais. Analisamos a postura do narrador bem como a imagem das tentativas falhadas de inclusão social do personagem com Síndrome de Down. Visamos encarar o romance para além de pressupostos biográficos e confessionais.

PAlavras-Chave: O filho eterno; anormalidade; Cristóvão Tezza; Foucault.

AвSTRACT: This article studies a number of theoretical aspects of Cristóvão Tezza's novel "O Filho Eterno". The study considers in particular Michel Foucaulst's theory about abnormality. The study analyzes the narrator's attitude as well as the images of the failed attempts of social inclusion of the character with Down Syndrome. The aim of the study is to consider the romance beyond biographical and confessional assumptions.

KEYwords: “O Filho Eterno”; abnormality; Cristóvão Tezza; Foucault.

" Doutor em Literatura pela Universidade Federal de Santa Catarina - UFSC. setepratas@hotmail.com 


\section{UM NARRADOR ANORMAL}

Cristóvão Tezza teria dito recentemente: “(...) já sou um narrador naturalmente impiedoso e, ao me transformar em personagem, pude bater em mim mesmo sem problema (...)" (MALISKA; FERREIRA). Minha primeira questão a partir do que parece anômalo: Estarão certos os leitores que pensam que Tezza realmente "transformou-se" em uma personagem exagerada, um protagonista impiedoso de uma narcísica autobiografia? Por que o narrador de "O filho eterno" parece-nos, em muitos sentidos, anormal? Arrastando para o lado de uma possível leitura psicanalítica, Maliska e Ferreira pensam no narcisismo do narrador de "O filho eterno" como fator que determinou no sujeito uma agressividade impiedosa contra o filho, para, ao mesmo tempo chegar a uma dada transcendência. Se talvez Tezza precisou se transformar neste personagem-pai impiedoso e narcísico para superar seus traumas, caberia a quem saber? Tal "agressividade" contra o destino é observada em muitíssimos momentos na narrativa, mas, neste artigo, desejaremos evadir o máximo possível da tese autobiográfica, a de uma literatura-terapêutica, por exemplo, para embarcar mais no viés político e estético que suscita a narrativa, o que é muito mais apropriado.

Na contracapa do livro, a explanação do crítico Jerônimo Teixeira propõe a "crueldade" como a grande qualidade do livro. Realmente, o personagem principal do romance traz um narcisismo quase tirânico, quando, por exemplo, ao não aceitar o filho anormal, naturalmente imagina sua morte. Em um mundo competitivo que funciona como uma corrida de cavalos pelas regras alheias, 0 narrador interroga diretamente, pensando no filho: "Mas não se matam cavalos?" (TEZZA, 2009, p.68).

A “anomalia" (se assim podemos dizer) maior do livro está nisto: a coragem autoral em respaldar a frieza do protagonista, um narrador impiedoso. Em alguns raros momentos, ao ver que Felipe não se encaixa no mundo homogeneizante que sistematiza e classifica os sujeitos como "uma linha de produção" (p.89), o pai até tenta situar-se ao lado do filho. Ele odeia qualquer lugar arquetípico e, certamente, ter um filho com Down, ao invés de tirá-lo do "lugar comum", o coloca justamente lá. Contrariando suas perspectivas, o protagonista deveria ser um verdadeiro pai, mais dedicado que um pai comum, um pai presente. No entanto, como o ideal individualista de ser escritor opõe-se a essa impessoalidade que um pai deve ocupar reduzindo-se a um pai presente e atento, ele é reenviado constantemente ao lugar que ele despreza: o "lugar comum". E o lugar comum não é o lugar dos escritores. Um dos primeiros momentos em que o pai aparentemente se põe ao lado do filho ocorre apenas na página 89 do romance, quando o narrador usa da $1^{\text {a }}$ pessoa do plural ("nós"), mas que assim mesmo continua a marcar o distanciamento entre o filho e as expectativas do pai utópico:

$\mathrm{O}$ pai começa a se sentir melhor. $\mathrm{Na}$ verdade, começa a ser tomado pela ideia de normalidade. É uma corrida, ele pensa prosaicamente, entrando 
de cabeça no lugar comum em que se encontra: é uma corrida e nós saímos lá de trás, mas com um bom trabalho, o menino vai alcançar os outros. (TEZZA, 2009, p.89) (Grifo nosso)

Assim, o livro é repleto de íntimas questões, ali postas totalmente às claras, de modo anômalo, levando qualquer leitor beato com relação à imagem do anormal, ou da família que cuida de uma criança anormal, a um choque crucial. O anormal na sociedade se torna ainda mais atípico, no ponto de vista do pai, o diferente se torna ainda mais diferente. É que Tezza não utiliza o olhar do pai para amenizar a crueldade que o portador de Síndrome de Down sofre na sociedade, ao contrário, ele cruelmente persevera no anormal como anômalo.

É de tal maneira que as primeiras impressões do livro poderiam parecer mesmo revoltantes para um leitor que nutrisse romantismos políticos e expectativas líricas de desfrutar de uma história onde o diferente, o menor, o anormal, estivesse representado como cerne heróico do livro. Ao contrário, a vergonha do filho é o que impera. Sobretudo no contraste com os sonhos do narrador em se tornar escritor, esta vergonha impera, mostrando o quanto o desejo de se destacar socialmente como escritor não passava ali de um desejo em descompasso com a verdadeira autenticidade da vida (que no caso do personagem é a de ter um filho Down).

\section{INCLUIR E/OU EXCLUIR}

Tendo em vista o uso deste narrador extremamente impiedoso, creio que com- pensa refletir sobre os lugares biopolíticos, assim digamos, que Tezza obtém, conscientemente ou não, em especial com relação ao lugar do anômalo em uma sociedade de controle constante. Penso que uma das contribuições críticas essenciais de "O filho eterno" reside no fato da obra levantar, com relação aos anormais, uma reflexão universal sobre as políticas de inclusão da criança deficiente.

Mais do que fazer uma mera publicidade do valor epistemológico da inclusão do anormal na sociedade, muito menos passear nos meandros existenciais da angústia familiar deste tema, a obra suscita as várias dificuldades que as chamadas práticas de inclusão têm confrontado na contemporaneidade. A crítica atua em vários contextos, sobretudo o escolar. "Como bem sabemos, tais políticas de inclusão - uma bandeira que tem atraído boa parte dos pedagogos progressistas - têm enfrentado dificuldades (...)" (VEIGA-NETO, p. 109)

Em um ensaio nominado "Incluir para Excluir", o professor foucaultiano Alfredo Veiga-Neto aborda a problemática das chamadas "classes inclusivas", onde a gênese persistena própria separaçãonormatizadora sob a qual os alunos são distribuídos em classe, a supor a sistematização de níveis, a igualização, a homogeneização das diferenças, etc. Este nexo normatizador foi um arranjo em decorrência da lógica moderna de normalização social cuja base de tal homogeneização é a própria diferenciação, logo a problemática não seria tanto a do "nível cognitivo" ao qual os alunos diferenciados, ditos anormais - com 
Trissomia do cromossomo 21, por exemplo não atingem.

Interessante que a imagem do anormal Felipe, apesar de suas anomalias cognitivas (de apreensão de conhecimentos), não revela nenhum ou quase nenhum problema em outros aspectos que, para o pai, por sua vez, representam dificuldade (como a timidez, a paranoia ou a depressão), ou seja, Felipe possui várias habilidades, sobretudo de socialização e entendimento do mundo presente, que minimamente o igualam ao pai ou até mesmo o superam. Creio que, por mais veladamente isso ocorra, Tezza caça menos a anormalidade específica do filho ou do pai, do que a anormalidade da própria sociedade - denunciando, assim, os controles biopolíticos e a construção hipocritamente equalizadora da imagem do anormal na sociedade. Nisso, Tezza é impiedoso com as hipocrisias da própria sociedade.

Especialmente, trechos de "O filho eterno" mostram bem o âmbito escolar como uma máquina de governamentalização, uma máquina mais eficaz que qualquer outro modo de controle. Desde o século XVII, a escola constitui-se, como diz VeigaNeto, "como a mais eficiente maquinaria encarregada de fabricar subjetividades" (VEIGA-NETO, 2006, p.34). Na narrativa, as buscas de inclusão nas "escolas normais", tanto quanto as buscas terapêuticas ou inclusivas em classes especializadas, sempre são frustrantes, afinal não passam daquilo mesmo que opera no discurso narrativo: toda tentativa de inclusão pura do anormal reincide na exclusão, no transbordamento da diferença. A única força efetiva é a da "inclusão como exclusão". Quaisquer promoções da inclusão não passam de esforços obsoletos. Nessa disposição incontornável, em "O filho eterno", acaba-se por questionar a instrução inclusiva brasileira, mostrando-a como agravamento de desigualdades pela tensão doutrinária, padronizadora, pelo velho teor comportamentalista (behaviorista), etc.

Nos acusam de criar macaquinhos com reflexos condicionados. Se for mesmo assim, por que não? Qual a opção?'. Sim, todos queremos crianças bem-educadas, com padrões de comportamento que não agridam os olhos ou a alma. Crianças que não provoquem olhares suspeitos em nossa direção, contra os pais, em última instância os responsáveis pelos seres errados (...)" (TEZZA, 2009, p.88)

Seria interessante remeter essa crítica tezziana ao modelo de controle político pela educação (adestramento do anormal) ao conceito de poder sobre o anormal trabalhado por Michel Foucault, em conferências dos anos 70 (refiro-me a algumas passagens do livro "Os Anormais").

O filósofo francês muito bem revelava uma transição histórica a uma nova modalidade de poder (ligado ao saber), ao analisar como a peste substitui a lepra como modelo de controle político, no séc. XVIII. Para Foucault, em linhas gerais, temos que reparar na "invenção das tecnologias positivas de poder" (FOUCAULT, 2001b, p.59). Na idade clássica, o poder que antes reagia negativamente à lepra (o poder que bane, exclui o anormal) passou a uma reação positiva, de inclusão. Desde então, 
a sociedade fabrica, observa, transforma, "multiplica efeitos de poder a partir do acúmulo da observação e do saber (...) um poder que se multiplica a partir de seus próprios efeitos" (FOUCAULT, 2001b, p.60). Para Foucault - como para Tezza - a educação (as escolas normais e a família) são meros prolongamentos de uma técnica de exercício da normalização disciplinar das crianças distintas, um princípio de inclusão no dispositivo positivo da normalidade, tal qual a própria dimensão da produção industrial regula os trabalhadores ou a organização hospitalar regula os doentes.

Podemos notar, em toda história de Felipe, que o corpo isolado não passa de um pino de um critério grupal ao qual ele é considerado pertencente. É nesse sentido que a família de Felipe jamais aparece como um oásis no deserto de problemas próprios da sua anormalidade. O livro torna-se frio. As tentativas de inclusão da família não deixam de ser uma prática de rejeição inconsciente e medrosa. O que deveria ser drama familiar dá, então, lugar ao cômico, ao humor negro. As figuras do pai e da mãe do "mongoloide" (p.43), que seriam as figuras particulares como essência familiar, aparecem muito desequilibradas. Se a mãe de Felipe não pensava como o pai, não rejeitava o filho tanto quanto ele, pouco importa. O narrador ignora a presença da mãe e acaba por parecer irrisória a sua afetividade, uma vez que a figura da genitora de Felipe é totalmente abrandada no decorrer da narrativa. Isto ocorre porque - na balança familiar que para Tezza é apenas mais uma máquina de controle do anormal - a mãe se apaga ao passo que a figura do pai (como ser que rejeita o filho) é, ao contrário, exacerbadamente acentuada.

A artificialidade desta relação entre filho e mãe é simbolicamente visível quando a criança anormal não acerta sugar o seio. Relembro que, para conseguir algumas gotas de leite, os pais precisam usar uma bombinha de borracha que separa o filho da naturalidade do aleitamento.

Indicam uma traquitana (o que lhe agrada, é claro): um pequeno funil de vidro com uma bombinha de borracha. Um objeto delicado: lembra-lhe algo antigo, uma farmácia de filme, um alquimista medieval. Aquilo suga o leite como um projeto de Da Vinci, ele fantasia. Gotas amareladas - não parece leite. (TEZZA, 2009, p.42)

Seja na escola, em casa, ou nos concursos de natação para crianças especiais, a presença da família, em "O filho eterno", não está ali para "incluir" o filho atípico, e sim "incluir para excluir". Isto talvez ocorra porque não é possível uma máquina de exclusão (a máquina familiar, no caso) abarcar a imagem do anormal como se fosse normal, em Tezza, mas sim e apenas - hipertrofiar anomalias para que elas fiquem visíveis o bastante, claramente distinguíveis. A família pode ser obstinada, porém, como instituição, jamais é resistente aos polos epistemológicos ou discursos morais que colocam o filho anormal na imagem de "indivíduo eventualmente perigoso" (FOUCAULT, 2001b, p. 43). A imagem negativa do pai para si mesmo e 
a da segurança da família para si mesma valem mais do que as possíveis imagens benéficas que Felipe poderia apresentar desde seu lugar "marginal" à normalidade. Os pais percebem, na escola normal, que essa imagem do "filho problema" transborda na sociedade. Ele é rejeitado pelos professores e lhes indicam encaminharem Felipe para "escolas especiais". A expressão da mãe sobre isto é submergida pela postura delirante/confessional paterna (a postura do delirante trágico), que vem a ser a de um misto de incumbência social com revolta.

\section{O OLHAR DA NORMALIZAÇÃO}

No fim, a mecânica biopolítica da normalização sempre abate a esperança familiar. Esta expectativa familiar, por sua vez, sempre é errônea e pueril, a de que o anormal fosse avaliado como normal entre normais, mesmo sabendo que é impossível implantar esta imagem em Felipe. Logo, a culpa se mescla com uma revolta ingênua contra "o Estado". Imediatamente, o protagonista sai da condição de pai que atende ao filho para assumir a condição do delirante trágico ${ }^{1}$, uma vez mais. Esta condição de de-

\footnotetext{
${ }^{1}$ As falas delirantes do pai são uma infantilização dele próprio, um modo do personagem fugir do presente. A postura de delirante trágico revela um retorno ao tempo de sua adolescência (sua ligação com a escrita). $O$ pai assume uma linguagem balbuciante, medrosa, onicircular, sem controle, perigosa, exercida por causa da desqualificação que Felipe provoca no pai. Por causa do medo, o pai torna-se moralizador e concorre com "a criança eterna" que é seu filho, por meio da postura de delirante trágico? Lembro que, em "Os Anormais", Foucault aproxima o discurso da moralização ao discurso do medo. A linguagem infantil vem a ser o discurso do medo, "linguagem balbuciante”. “(...) Ele fala a linguagem da criança, a linguagem do medo, logo ele, que é o cientista, que está ao
}

lirante trágico associa-se à juvenil imagem anormal que ele cultivou desde antes de sua adolescência rebelde. Para o pai, o tiro sempre sai pela culatra. Contendo a revolta e o narcisismo como combustíveis, o pai reincide no inconsciente e cruel desejo de morte do filho.

Por que diabos alguém teria a obrigação de cuidar do meu filho?! - o Estado, ele pensa, de estalo, lembrando o amigo candidato de anos atrás, a gravidade com que alçou a cabeça para lembrar o pequeno Leviatã nosso de todo dia, o Estado é responsável por isso. $\mathrm{Na}$ esquina, o filho quer pipoca, e o pai recusa, ríspido, puxando-lhe pela mão, está quase na hora do almoço-a criança obedece imediatamente. O Estado, ele pensa. Seu filho só está vivo porque existe o Estado, o monstro abstrato - ao acaso da tribo ou da natureza, o seu filho estaria morto em três dias úteis" (TEZZA, 2009, p.158)

Interessante como a memória dos protagonistas em Tezza torna-se, frequentemente, motor potencializante do trágico. Justamente na busca de boas clínicas especializadas em trato de crianças anormais é que os pais, no romance, aprendem a "síndrome dos pais com filhos lesados" (p.84). Ante uma poderosa civilização normatizadora, fundada na vontade coletiva que exclui, quer seja, naquilo que recusa imagens anormais, o pai de Felipe vai aprendendo esta espécie de "síndrome" dos pais que se tornam tão anormais quanto seus filhos.

$\overline{\text { abrigo, protegido, sacralizado até, por toda a instituição }}$ judiciária e sua espada. Essa linguagem balbuciante (...)" (FOUCAULT, 2001b, p.45) 
Uma síndrome que se demonstra em olhares aflitos, frios, rostos com marcas específicas, tensões, articulações culposas, sempre uma desculpa na ponta da língua. A família do anormal sempre está no banco dos réus.

Mais do que aquele olhar usual das protagonistas de Tezza (olhar de uma "máquina pensante") este personagem-pai-de-Felipe passa a ser um pensador obsessivo pelos detalhes, pela operação que distingue as semelhanças das diferenças. Quanto mais se busca a inclusão do filho, mais olhar do pai é, crescentemente, um olhar da sensibilidade concreta, que se dá pelo golpe de vista, esquadrinhando a tudo. Tal olhar, confuso entre narrador e protagonista, acabaria por ocupar, assim, um "olhar clínico", na acepção foucaultiana? Lembremos: "O olhar clínico é um olhar que queima as coisas até sua extrema verdade (...)" (FOUCAULT, p. 136).

Todo modo um olhar complexo. O olhar do personagem é composto filtrado à maneira do narrador em terceira pessoa que, como diria Marisa Lajolo, “(...) em certos momentos trata o ele como tu, ou seja, o protagonista pai-do-Felipe desliza para uma segunda pessoa" (LAJOLO, s/p). Ou, citando o próprio autor que diz em entrevista: “(...) é uma terceira pessoa permeável, que avança frequentemente para a cabeça do personagem." (TEZZA, s/p). Nesta técnica tezziana (a de um complexo olhar em terceira pessoa "permeável"), o narrador assume intimidade absoluta com o protagonista e seus ativos pensamentos, abstrações onicirculares, crueldades, frustrações, no entanto, não entra muito em conexão com o olhar singelo, passivo, de Felipe, que vem a ser o segundo protagonista da história. Penso que teríamos, mesmo, que reavaliar se Tezza alcança o que se propôs ao optar pela terceira pessoa, e se ela não poderia ter um efeito tão dramático e cômico quanto aí está em terceira, acaso estivesse em primeira pessoa. Pois é uma terceira pessoa que exclui todos os olhares das outras personagens da história e que, de algum modo, ocupa o posto de uma primeira pessoa, de um "eu" (o pai).

O olhar do excluído, do "Pitusco" (Felipe), por sua vez, é o olhar simples do eterno paciente, o paciente impaciente, objetivado, que vê a vida como desenho animado, aquele que quer observar tudo ao seu modo colorido por mais oponha-se à tentativa de mimetizar comportamentalmente o real. "O menino gosta de pôr óculos escuros, sentar-se numa cadeira desmontável e gritar: Câmera! Ação! (...)" (TEZZA, 2009, p.188).

$\mathrm{Na}$ obra - em muitos momentos em que Felipe compete com outros, ajusta-se, ou tenta falivelmente adequar-se às crianças normais - a inclusão real do aluno é revelada como improvável. O filho eterno é, também, o eterno estrangeiro. Apesar disso, Felipe demonstra sempre a naturalidade da normalização que ele sofre e, por outro lado, a falta de neutralidade da educação, como prática de dominação que perpassa toda sua vida social ${ }^{2}$. Felipe não tem a mínima

\footnotetext{
2 "Afinal, educar o outro é trazer esse outro para a nossa cultura, sejam eles os recém-chegados - crianças ou estrangeiros- ou sejam aqueles que consideramos passíveis de inclusão —os anormais ou os estranhos. 'Ao educar o outro, nós o aproximamos de nossa morada, do nosso domínio, graças a variadas formas de dominação que estabelecemos com ele e, muitas vezes, sobre ele'. (Veiga-Neto, 2006, p. 30). Isso não significa que a
} 
concepção de valor ou dimensão de cânone. "Para ele, é claro, a distância entre uma palhaçada qualquer repetida à mesa três vezes e o artista declamando Shakespeare é nenhuma (...)" (p.189). Mais que o fato do filho ser problemático ou possuir um nível cognitivo raso, Tezza revela que aquilo que advém como problemático é o próprio sistema educacional enquanto aparelhamento de normalidades. É o sistema moralizador e hierarquizador da escola que trabalha para enfatizar importâncias históricas e valores subjetivos repetitórios, e jamais para consagrar o possível olhar criativo e diferencial dos anormais.

A dificuldade da escola em disciplinar Felipe condiz com um modelo de idealização moderna, próprio de uma sociedade de práticas de dominação coletiva da diferença e dos diferentes, ou melhor, aquilo que Foucault nominara como "sociedade disciplinar". O livro trabalha não apenas o tema das preocupações paternas com um filho anormal, mas tange o tema da inadequação deste pai com relação às preocupações bio-

educação seja neutra. Ao contrário, ela sempre se movimenta balizada pelos valores que são próprios da cultura daqueles que educam. Além do mais, ela sempre produz valores. Mas tais valores não lhe são intrínsecos, senão que lhe são agregados por aqueles que educam, segundo a própria cultura da qual fazem parte. Por isso, não basta saber educar; é preciso saber para onde se conduz aquele que se educa. / Por tudo isso, pode-se dizer que as práticas de dominação perpassam todas as instâncias da vida social e implicam movimentos de resistência e de contracondutas. Ambos os movimentos - de resistência e de contraconduta-, por serem mobilizados em relações de governamento e de poder, contam com o convencimento da população sobre a importância de ter, sob o seu domínio, alguns atores da vida cotidiana. Entre tais atores, temos, por exemplo, os loucos, os desempregados, os criminosos, os delinquentes, os pobres, os anormais, os deficientes. (...)" (VEIGA NETO, A. e LOPES, M. C., p. 4) políticas da própria sociedade, ou seja, as preocupações de governabilidade indireta que, por meio da gestão da saúde mental e física, vai planeando e modelando a vida da população. Acredito que Tezza proporciona uma crítica ontológica às classes escolares ditas "inclusivas", operantes em um dispositivo prometeísta que, no fundo, continua a obrar a educação no velho olhar de incluir para distinguir. Como diria Veiga-Neto:

Se parece mais difícil ensinar em classes inclusivas, classes nas quais os (chamados) normais estão misturados com os (chamados) anormais, não é tanto porque seus (assim chamados) níveis cognitivos são diferentes, mas, antes, porque a própria lógica de dividir os estudantes em classes - por níveis cognitivos, por aptidões, por gênero, por idades, por classes sociais, etc - foi um arranjo inventado para, justamente, colocar em ação a norma, através de um crescente e persistente movimento de, separando o normal do anormal, marcar aquela distinção (...)" (VEIGA-NETO, pp.110,111)

\section{O NARCISISMO DO PAI}

A imagem do filho anormal não apresenta nenhuma "exotopia", opai, por sua vez, vive fora de seu próprio lugar histórico por desejar ser um escritor destacado. Ou, como dirá Magalhães, em sua dissertação de mestrado: “(...) O filho do personagem é sempre alguém mostrado como alguém sem a menor exotopia. Vive para si mesmo, em si mesmo." (MAGALHÃES JUNIOR, p. 182). $O$ personagem do pai também não deixa de 
viver só para si mesmo e em si mesmo, claro está. Apenas ocorre que no filho é o egoísmo doentio, grosseiro, que atua, já no pai é o egoísmo narcísico, delicado, literário; pois o problema do filho é mental e o do pai é, basicamente, moral. Não queremos, óbvio, moralizar a narrativa, ou afirmar com isto alguma falta grave na escrita tezziana em sua autobiografia (aliás, já chegaremos a este ponto, pois não considero esta escrita integralmente autobiográfica), mas sim que Tezza tece uma espécie de ficcionalização lírica de si mesmo na situação de um poeta imaturo que não liga para o mundo mas, contraditoriamente, acredita na pura autenticidade, na pessoalidade conferida pelo olhar do outro. Um escritor acabrunhado na genialidade, produzindo textos piegas como "O Filho da Primavera", na busca de conquistar o seu direito mesmo de ser um escritor, do mesmo modo com que o filho deveria buscar seu direito de ser um filho. “(...) Sim, essa brutalidade faz sentido, ele pensa - talvez (isso ele não pensa) de fato a criança tenha de conquistar o seu direito de se tornar um filho (...)" (TEZZA, 2009, p.105).

Do mesmo modo, será que Tezza estaria tentando conquistar o direito de escrever sobre seu filho? Em meu ponto de vista, as possíveis "falhas" de Tezza, em seu romance, aproximam-no do paradoxo confessional que Blanchot demonstra nas autobiografias de Rousseau, por exemplo. Assim como Rousseau, Tezza quereria "dizer tudo", manter-se sob seus próprios olhos, e isto passaria por dizer aquilo que o incrimina (e pode desculpá-lo). A minha impressão ao ler o romance "O filho eterno" é a de que o autor sempre está voltando a dizer, voltando ao começo, perturbando o leitor (com uma espécie, talvez, de mongolismo escritural?), voltando ao princípio de sua história, de sua culpa, de um eterno retorno que falha. ${ }^{3}$

Todo o livro circula, como não poderia deixar de ser, em temas fortes como o "desejo de morte", "vergonha", "medo da exposição", "horror ao espelho" e outros. Diz Magalhães: “(...) Tezza coloca questões cruciais sobre a relação entre pai e filho e revela a intimidade dos pensamentos mais secretos deste escritor personagem, que chega a, por exemplo, desejar a morte do próprio filho." (MAGALHÃES JUNIOR, p. 157).

Há uma profusão de pressupostos extremamente egoístas aí: não importa a criança, o que está em jogo é a vida do pai; a criança não é vista como uma pessoa, mas como um problema sem solução; o personagem principal coloca-se não só como vítima mas também como "sentido e finalidade última" dos fatos, que só ganham importância à medida que interferem em sua vida; o personagem isenta-se de qualquer responsabilidade sobre o filho;

\footnotetext{
${ }^{3}$ Vejamos que Blanchot dirá sobre as "Confissões" de Rousseau o seguinte: "(...) Se ele não cessa de escrever sobre si mesmo, recomeçando incansavelmente sua autobiografia, sempre interrompida em certo momento, é porque está, incessante e febrilmente, em busca do começo que falha sempre ao ser expresso, enquanto, antes de qualquer expressão, ele tem a calma e a feliz certeza do começo. "Quem sou eu" - assim começam as Confissões, em que ele quer não apenas mostrar-se "por inteiro ao público" mas também manter-se "incessantemente sob seus próprios olhos" (BLANCHOT, O livro por vir, 2005, p. 63)
} 
imputa toda essa responsabilidade à esposa (que, ademais, sempre fora seu esteio emocional e financeiro). (LORENZI, s/p)

Tal narcisismo acabaria (ao ser exteriorizado em palavras, reminiscências textuais) por lançar a transcendência do ideal egoísta que antes constituía a miragem de si mesmo? Neste viés, nos perguntamos ainda, terá sido a produção do livro, para Tezza, realmente um modo de "bater", rebater, remoer, dar palavras, conferir significados, um modo inconscientemente psicanalítico, terapêutico, de entender sua complexa relação com o filho portador de Síndrome de Down? Encarando rigidamente por tal perspectiva, reitero que perigaríamos cair em uma interpretação genuinamente autobiográfica do livro "O filho eterno", ou melhor, uma interpretação freudiana que colocaria a ficção no mesmo patamar da confissão; o autor no mesmo patamar de um paciente. Porém, acredito que o leitor não pode estar no mesmo patamar de um psicanalista que investiga o inconsciente de Tezza, pois está apenas a ler um romance. Neste caso, qual é a relação do autor com sua escrita?

Será que ela precisa ser terapêutica? O autor, no seu ofício de criar, está fazendo uma catarse? E essa autoanálise ficcional será completa, uma vez que a linguagem nem sempre consegue dar conta de todas as formas de expressão, gestos e manifestações, que, numa consulta de análise, o terapeuta poderia identificar? Como se dá essa projeção na escrita? E a construção desse ser-ficcional? (MARTINS, p. 14)
UMA BIOGRAFIA ANÔMALA. UMA "AUTOFICÇÃO"

Retomando a fala de Cristóvão Tezza: “(...) ao me transformar em personagem, pude bater em mim mesmo sem problema" (Op. cit), outras perguntas sucedem-se: terá sido a produção deste livro, para Tezza, um modo de "bater" em si mesmo no sentido de suprimir-se da experiência real de pai criando outra experiência, fictícia? Se o autor colocou, pelo trabalho de construção de romance, um "outro" em seu lugar, até que ponto poderei afirmar que o enredo ocorre marginalmente à biografia possível, ao passo que ele também usou de pressupostos biográficos para produção de uma ficção? Nesses termos, idealizaríamos Tezza como autor de um romance qualquer, sem nenhum traço de autobiografia, no entanto, não me parece ser o caso. Gostaria de remeter às palavras de Silvia Molloy, acerca da autobiografia, quando ela afirma que:

A autobiografia é sempre uma re-presentação, ou seja, um tornar a contar, pois a vida a que supostamente se refere é, por si mesma, uma construção narrativa. A vida é sempre, necessariamente, uma história; história que contamos a nós mesmos como sujeitos, através da rememoração; ouvimos sua narração ou a lemos quando a vida não é nossa. (...) A autobiografia não depende de acontecimentos, mas da articulação destes eventos armazenados na memória e reproduzidos através da rememoração e verbalização. 'Meu nome, mais do que nomear, me lembra meu nome'. A linguagem é a única maneira de que disponho 
para 'ver' minha existência. Em certo sentido, já fui 'contado' - contado pela mesma história que estou narrando. (MOLLOY, 2004, p.19)

Devemos encarar a autobiografía não apenas como o mais referencial dos gêneros, porém como uma "re-presentação", um tornar a contar aquilo que já é sempre necessariamente uma história contada e a ser contada.

De modo geral, a dimensão crítica a este romance o qualifica no meio-termo entre a autobiografia e a ficção pura. Lembremos que Blanchot postulava que mesmo um diário, como modalidade autobiográfica, exprime, mais do que o registro de uma vida, o estranhamento de um outro que substitui o "eu". O registro da vida não é exatamente confissão de si mesmo, mas um memorial, lembrete de quem o autor é, na ausência da escritura, ou seja, aquilo que se é ao não escrever ${ }^{4}$. Quem sabe “(...) como sugeriu Blanchot, as formas autobiográficas canônicas sejam escapes verdadeiros da alienação do escritor no texto de ficção, da solidão do si mesmo à qual chega pelo caminho de sua obra(...)" (ARFUCH, Leonor, 2010, p.233)

\footnotetext{
${ }^{4}$ Em "O livro por Vir", Blanchot fala, igualmente, sobre o que haveria no Diário de Virginia Woolf: “(...) notas que dizem, às vezes solenemente, a falta ao nível da qual seu trabalho a conduz: "Quero obrigar-me a olhar de frente a certeza de que não há nada, nada para nenhum de nós. Trabalhar, ler, escrever são apenas disfarces;assim como as relações com as pessoas. Sim, mesmo ter filhos não serviria para nada." Não é um pensamento herdado passageiramente de seu meio; é uma convicção que sente intimamente ligada à verdade de sua tarefa: ela precisa encontrar o vazio ("a grande agonia", "o terror da solidão", "o horror de contemplar o fundo da lama”)(...)” (BLANCHOT, O Livro por vir, p. 144)
}

Acredito, por um viés blanchotiano, que o drama essencial encenado por "O filho eterno" é o da subjetividade da ausência como aquele que resgata sua autoimagem de pai, ou seja, a solidão autoral do escritorpai seria talvez mais absorvente que o próprio drama da sua vivência naquilo que diz como sendo pai real de Felipe. Assim, Tezza teria rememorado certos fatos, mas, também convenhamos, teria adicionado um máximo grau de picância em várias emoções, em vários anseios reais e lembranças de suas próprias pretensões juvenis de escritor e de pai. Apresentaria, de tal modo, um personagem muito mais burlesco, mais escrachado. Um protagonista-pai antes englobado pelas características comuns de sua própria escrita, de seu estilo, do que como produto de uma recordação de si. Ao contrário de uma reminiscência sentimental paterna, ao cunhar este romance, o autor assinala, antes, o dilema da incredulidade em um espaço autobiográfico como memorização da vida. Penso que Tezza tentou ir contra políticas estabelecidas, ratificando que toda autobiografia, como gênero sentimental, é eternamente impossível. A título de curiosidade, note-se que um dos estilos de Tezza incide, justamente, na dificuldade de lidar com o plano do sentimentalismo.

Como já vimos em todos os outros livros, Tezza está sempre um pé atrás em relação ao sentimentalismo, ao qual não concede nem uma linha, a consciência sempre alerta contra os apelos sentimentais, os quais são constantemente carnavalizados, es- 
crachados, questionados, relativizados. (MAGALHÃES JUNIOR, p. 165)

De tal modo, podemos argumentar que este seu romance, ao mediar as suas memórias da experiência pessoal com a criação de um personagem diferente de si mesmo, produz uma variante de "autoficção". Não é apenas o caso de um autor que, de súbito, se autoanalisa por intermédio da palavra/escritura (pressuposto psicanalítico), mas sim o caso de uma escrita que eternamente alude a si mesma, como processo de composição de verdades, e que desconfia da autenticidade de um resgate da experiência pelo relato.

A autoficção, enquanto variante pós-moderna da autobiografia, não acredita mais na possibilidade de escrita autobiográfica à maneira de Lejeune. Ela é a descrença em uma verdade literal e na autenticidade de uma experiência posta em relato. $O$ discurso subjetivo e circunscrito à esfera da memória é falível, e, por isso, Doubrovsky aposta na 'reconstrução arbitrária e literária de fragmentos esparsos de memória', ou seja, na autoficção. / Neste sentido, a autoficção é autorreferencial, metatextual e metaficcional. Assim, numa perspectiva literária, a inserção da experiência analítica na narrativa corresponde a uma reflexão profunda sobre a produção da literatura por ela mesma e sobre a escritura autoficcional. (...) / Outra especificidade da autoficção é o seu importante acordo com a psicanálise. A escrita de si é a escrita da autoanálise. Esta é uma escritura autoanalítica e autorreferencial. Hubier ressalta a prática da cura, a metapsicologia e o seu método tomado emprestado de Freud. Fala também na projeção. O autor de autoficção projeta no livro (sua criação, por isso, seu "filho", que é dependente dele e só existe porque ele o geriu/escreveu), isto é, no universo fictício, a história da sua vida, a sua experiência individual, os seus traumas, os recalques, toda a matéria de seu romance faz parte daquilo que ele precisa e quer exteriorizar, em busca da autocompreensão, do entendimento e, por conseguinte, da autoanálise. (MARTINS, p.12)

O sujeito narrador, nesta ocorrência ficcional, não pode ser meramente autobiográfico, pois a matiz narrativa estaria mais para o "autoficcional". ${ }^{5}$ Mesmo assim, o que mais desponta em "O filho eterno" vem a ser a extrema desconfiança em qualquer modalidade de resgate que ponha em evidência o já vivido. É deste modo que quiçá algo parece como destoante no livro, podendo destoar das expectativas dos leitores. Estamos ante uma biografia anômala.

Por outro lado, independentemente do plano biográfico, Tezza alcança outras decorrências de sentido crítico que vão além do tema da anormalidade específica da Síndrome de Down. Até certo ponto, ele

\footnotetext{
${ }^{5}$ Mesmo sem querer fixar um gênero de narração para este romance, tendo a concordar que "(...) O filho eterno é uma autoficção, ou seja, o autor ficcionaliza uma experiência pessoal, publicamente revelada, mas quer que o livro seja lido como romance. Podemos dizer, ainda, que é uma atualização do conceito original de autoficção, uma vez que o autor abre mão do uso singular da primeira pessoa e adota, como estratégia literária, a terceira pessoa do Romance, como quer Barthes. Trata-se de uma escrita do $e u$, em que o eu do discurso referencial se projeta no ele, máscara da ficção." (MARTINS, Anna Faedrich. p. 10)
} 
tira proveito da anormalidade do filho (um tema ligado à sua efígie pessoal), pelo exercício da autoficção, para criticar algo que está na sintomatologia do anormal. Assim, penso que o desenho cultural do anormal, o modo como o anormal é em geral ilustrado e incluído/excluído em uma sociedade (mais anormal ainda) é o que antes se expõe em "O filho eterno". Com certeza, é um de seus livros mais audaciosos e desestabilizadores.

\section{REFERÊNCIAS}

ALMEIDA, M. B. de. Resenha de O filho eterno de Cristovão Tezza. Revista Estudos Feministas [On-line] 2009, 17 (Enero-Abril). Disponível em: http://www.redalyc.org/ articulo.oa?id=38114360017. Acesso em 10 jun 2014

ARFUCH, L. O Espaço Biográfico. Dilemas da Subjetividade Contemporânea. Rio de Janeiro: UERJ, 2010.

BLANCHOT, M. O Livro por Vir. São Paulo: Martins Fontes, 2005.

\section{BAUDRILLARD, J. A transparência do}

Mal. Ensaio sobre os fenômenos extremos. Campinas: Editora Papirus, 1990.

FOUCAULT, M. O nascimento da clínica, trad. Roberto Machado, rio de Janeiro: Forense Universitária, 2001 a.

Os anormais. Rio de Janeiro:

Martins Fontes, $2001 \mathrm{~b}$.

LAJOLO, M. Um autor, um narrador e nenhum herói. Revista Linha Mestra, no 5, Disponível em: http://www.cristovaotezza. com.br/critica/ficcao/f_filhoeterno/p_13_ marisa_lajolo.htm Acesso em: 11 jun 2014.

LORENZI, C.L. Pavanelli de.Uma aproximação da crítica literária à psicanálise na leitura de O filho eterno, de Cristóvão Tezza: relações entre leitor, narrador e personagem. In: J. psicanal. vol.45, no.82, São Paulo, jun. 2012.

MALISKA, M. E.; FERREIRA, C. L. dos A. O Filho Eterno, um olhar paterno: o narcisismo na obra de Cristovão Tezza. In: Introdução ao Narcisismo, Correio APPOA, Porto Alegre, abril de 2004. Disponível em: http://www. appoa.com.br/correio/edicao/233/o_filho_ eterno_um_olhar_paterno_o_narcisismo_ na_obra_de_cristovao_tezza/88. Acesso em: 05 jun 2014.

MAGALHÃES JUNIOR, C. P. O conceito de exotopia em Bakhtin: uma análise de $\mathrm{O}$ filho eterno, de Cristovão Tezza. Dissertação de Mestrado, Curitiba: UFPR, 2010. Disponível em: http://dspace.c3sl.ufpr.br/dspace/ bitstream/handle/1884/24251/caibar $\% 20$ dissertacao\%2ofinal.pdf?sequence=1. Acesso em: 09 jun 2014.

MARTINS, A. F. Uma discussão teórica acerca da autoficção: a ficcionalização de si em $O$ filho eterno, de Cristovão Tezza. In: Letrônica, Porto Alegre v.4, n.1, p.190, jun./2011.

MOLLOY, S. Vale o escrito. A escrita autobiográfica na América Latina. Trad. Antônio Carlos Santos. Chapecó: Argos, 2004. TEZZA, C. Cristóvão Tezza: Um escritor não pode ter medo de nenhum tema (entrevista com o autor). Expresso - Sup. Actual. Lisboa, Portugal, 2008. Disponível em: http:// bibliotecariodebabel.com/tag/cristovaotezza/. Acesso em 11 jun 2014.

O filho eterno. $7^{\mathrm{a}} \mathrm{Ed}$. Rio de Janeiro: Record, 2009.

Breve espaço entre cor e sombra, Rio de Janeiro: Rocco, 1998.

VEIGA-NETO, A. Incluir para Excluir. In: Habitantes de Babel. Políticas e Poéticas da 
Diferença. Org. Jorge Larrosa e Carlos Skliar, Belo Horizonte: Autêntica, 2001.

- Dominação, Violência, Poder e Educação escolar em Tempos de Império. In: Figuras de Foucault. Margareth Rago e Alfredo Veiga-Neto (org.), Belo Horizonte: Autêntica, 2006. . ; LOPES, M. C. Governamentalidade, Biopolítica e Inclusão. Disponível em: http://www.michelfoucault.com.br/files/ Colombia\%2oInclus\%C3\%A30\%20e\%20 governament\%20-\%2012dez10.pdf . Acesso em 16 jun 2014

Recebido para publicação em 15 de jul. de 2014 Aceito para publicação em 27 de Ago. 2014. 